\title{
Bruck syndrome
}

INSERM

\section{Source}

INSERM. (1999). Orphanet: an online rare disease and orphan drug data base. Bruck syndrome. ORPHA:2771

Bruck syndrome is characterised by the association of osteogenesis imperfecta and congenital joint contractures. 